\title{
Discoid Rash
}

National Cancer Institute

\section{Source}

National Cancer Institute. Discoid Rash. NCI Thesaurus. Code C117105.

A disc-shaped patch(es) of skin inflammation that is red, raised, and scaly; it typically develops on the face, scalp, and neck, and often leaves scars and dyspigmentation as a result of postinflammatory hyperpigmentation. 